Tertiary basins of Spain the stratigraphic record

\title{
of crustal kinematics
}

Edited by

PETER F. FRIEND AND CRISTINO J. DABRIO

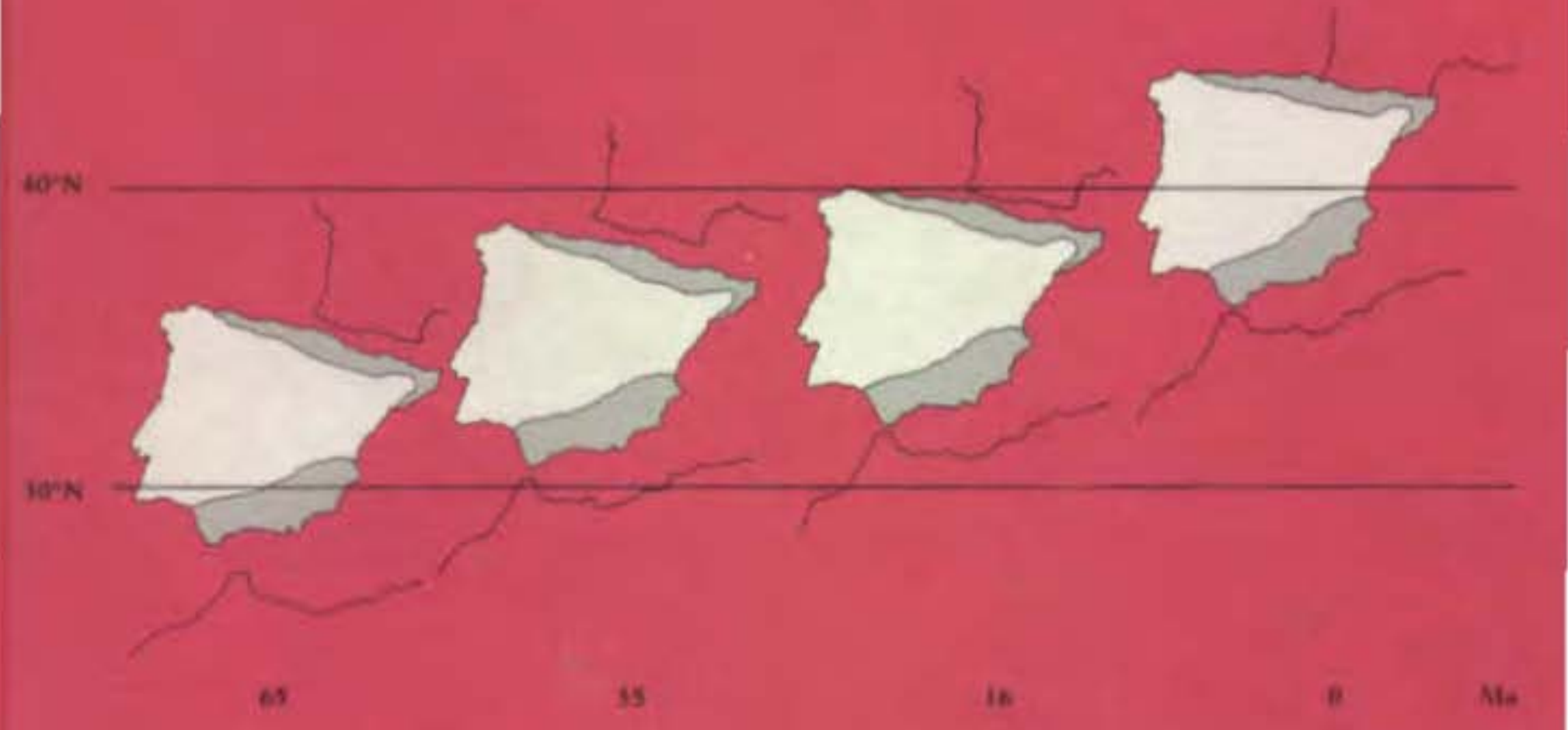

\section{World and Regional Geology 6}

CAMBRIDGE UNIVERSITY PRESS 


\section{Tertiary basins of Spain}

the stratigraphic record of crustal kinematics

EDITED BY

PETER F. FRIEND

Department of Earth Sciences, University of Cambridge

AND

CRISTINO J. DABRIO

Departamento de Estratigrafia, Facultad de Ciencias Geológicas and Instituto de Geologia Económica, CSIC, Universidad Complutense, Madrid, Spain 
Published by the Press Syndicate of the University of Cambridge

The Pitt Building, Trumpington Street, Cambridge CB2 1RP

40 West 20th Street, New York, NY 10011-4211, USA

10 Stamford Road, Oakleigh, Melbourne 3166, Australia

(C) Cambridge University Press 1996

First published 1996

Printed in Great Britain at the University Press, Cambridge

A catalogue record for this book is available from the British Library

Library of Congress cataloguing in publication data

Tertiary basins of Spain : the stratigraphic record of crustal kinematics / edited by Peter F. Friend and Cristino J. Dabrio.

p. cm. - (World and regional geology series)

Includes bibliographical references.

SBN 0521461715

1. Geology, Stratigraphic-Tertiary. 2. Geology, Structural-

Spain. 3. Basins (Geology) - Spain. I. Friend, P.F. II. Dabrio,

Cristino J. III. Series.

QE691.T465 1995

$551.7^{\prime} 8^{\prime} 0946-\mathrm{dc} 20 \quad 94-21724$ CIP

ISBN 0521461715 hardback 


\section{Contents}

List of contributors

Preface P.F. FRIEND and C.J. DABRIO

ix

Dedication to Professor Oriol Riba I Arderiu C. PUIGDEF ÁBREA Memorial, Etienne Moissenet 1941-1994 P. ANADÓN, N. MOISSENET and O. R IBA

\section{PART G GENERAL}

G!. Tertiary stages and ages, and some distinctive stratigraphic approaches P.F. FRIEND

G2. Cenozoic latitudes, positions and topography of the Iberian Peninsula A.G. SMITH

G3. Tertiary tectonic framework of the Iberian Peninsula C.M. SANZ DE GALDEANO

G4. Deep crustal expression of Tertiary basins in Spain E. B A NDA

G5. Oil and gas resources of the Tertiary basins of Spain F. MELÉNDEZ-HEVIA and E. ALVAREZ DE BUERGO

G6. Mineral resources of the Tertiary deposits of Spain M. A. GARCíA DEL CURA, C.J. DABRIO and S. ORDÓÑEZ

\section{PART E EAST}

E1. Geological setting of the Tertiary basins of Northeast Spain P. ANADÓN and E. ROCA

E2. The lithosphere of the Valencia Trough: a brief review M. TORNÉ

E3. Depositional sequences in the Gulf of Valencia Tertiary basin W. MARTÍNEZ DEL OLMO

E4. Neogene basins in the Eastern Iberian Range P. ANADóN and E. MOISSENET

E5. The Tertiary of the Iberian margin of the Ebro basin: sequence stratigraphy

J. Villena, G. PARDo, A. PEREZ, A. MUÑoz and A. GONZÁLEZ

E6. Tertiary of the Iberian margin of the Ebro basin: paleogeography and tectonic control J. Villena, G. PARDO, A. PÉREZ, A. MUÑoZ and A. GONZÁLEZ

E7. Stratigraphy of Paleogene deposits in the SE margin of the Catalan basin (St. Feliu de Codines St. Llorenç del Munt sector, NE Ebro basin)

J. CAPDEVILA, E. MAESTRO-MAIDEU, E. REMACHA and J. SERRA ROIG

68
E8. Onshore Neogene record in NE Spain: Vallès-Penedès and El Camp half-grabens (NW Mediterranean) L. CABRERA and F. CALVET

E9. The Paleogene basin of the Eastern Pyrenees J. M. COSTA, E. MAESTRO-MAIDEU and CH. BETZLER

E10. The Neogene Cerdanya and Seu d'Urgell intramontane basins (Eastern Pyrences) E. ROCA

E1 1. Eocene-Oligocene thrusting and basin configuration in the eastern and central Pyrenees (Spain) J. VERGÉS and D.W. BURBANK

E12. The Late Eocene - Early Oligocene deposits of the NE Ebro basin, west of the Segre River E. MAESTRO-MAIDEU and J. SERRA ROIG

9 E13. Chronology of Eocene foreland basin evolution along the western oblique margin of the South-Central Pyrenees P. BENTHAM and D.W. BURBANK

E14. Evolution of the Jaca piggyback basin and emergence of the External Sierra, southern Pyrenees P.J. HOGAN and D.W. BURBANK

26 E15. Long-lived fiuvial palaeovalleys sited on structural lineaments in the Tertiary of the Spanish Pyrenees S.J. VINCENT and T. ELLIOTT

E16. Evolution of the central part of the northern Ebro basin margin, as indicated by its Tertiary fluvial sedimentary infill P.F. FRIEND, M.J. LLOYD, R. MCELROY, J. TURNER, A. VAN GELDER and S.J. VINCENT

49 E17. The Rioja Area (westernmost Ebro basin): a ramp valley with neighbouring piggybacks M.J. JURA DO and O. RIB A

\section{PART W WEST}

W1. The Duero Basin: a general overview J.1. SANTISTEBAN, R. MEDIA VILLA, A. MARTÍN-SERRANO and C.J. DABRIO

W2. Alpine tectonic framework of south-western Duero basin J.I. SANTISTEBAN, R. MEDIAVILLA and A. MARTÍNSERRANO

W3. South-western Duero and Ciudad Rodrigo basins: infill and dissection of a Tertiary basin

J.I. SANTISTEBAN, A. MARTÍN-SERRANO, R. MEDIA VILLA and C.J. DABRIO

89 W4. Toctono-sodimentary evolution of the Ajmazán basin, NE Spain J. BOND 
W5. Tertiary basins and Alpine tectonics in the Cantabrian Mountains (NW Spain)

J.L. ALONSO, J.A. PULGAR, J.C. GARCíA-RAMOS and P. BARBA

W6. Lacustrine Neogene systems of the Duero Basin: evolution and controls

R. MEDIAVILLA, C.J. DABRIO, A. MARTÍN-SERRANO and J.I. SANTISTEBAN

W7. North-western Cainozoic record: present knowledge and the correlation problem

A. MARTÍN-SERRANO, R. MEDIAVILLA and J.I.

SANTISTEBAN

W8. Onshore Cenozoic strike-slip basins in NW Spain

L. CABRERA, B. FERRÚS, A. SÁEZ, P.F. SANTANACH and

J. BACELAR

W9. Tertiary of Central System basins

A. MARTÍN-SERRANO, J.I. SANTISTEBAN and

R. MEDIAVILLA

\section{PART C CENTRE}

C1. Structure and Tertiary evolution of the Madrid basin G. DE VICENTE, J.M. GONZÁLEZ-CASADO, A. MUÑOZMARTÍN, J. GINER and M.A. RODRÍGUEZ-PASCUA

C2. Neogene tectono-sedimentary review of the Madrid basin G. DE VICENTE, I.P. CALVO and A. MUÑOZ-MARTÍN

C3. Sedimentary evolution of lake systems through the Miocene of the Madrid Basin: paleoclimatic and paleohydrological constraints

J.P. CALVO, A.M. ALONSO ZARZA, M.A. GARCÍA DEL CURA, S. ORDǴNEEZ, J.P. RODRÍGUEZ-ARANDA and M.E. SANZ-MONTERO

C4. Paleomorphologic features of an intra-Vallesian paleokarst, Tertiary Madrid Basin: significance of paleokarstic surfaces in continental basin analysis

J.C. CAÑA VERAS, J.P. CALVO, M. HOYOS and S. ORDóÑEZ

C5. Tectono-sedimentary analysis of the Loranca Basin (Upper

Oligocene-Miocene, Central Spain): a 'non-sequenced' foreland basin

J.J. GÓMEZ FERNÁNDEZ, M. DÍAZ-MOLINA and A. LENDÍNEZ

C6. Paleoecology and paleoclimatology of micromammal faunas from Upper Oligocene - Lower Miocene sediments in the Loranca Basin, Province of Cuenca, Spain R. DAAMS, M.A. ÁLVAREZ SIERRA, A.J. VAN DER MEULEN and P. PELÁEZ-CAMPOMANES

C7. Fluvial fans of the Loranca Basin, Late Oligocene - Early Miocene, central Spain

M. DÍAZ-MOLINA and A. TORTOSA
C8. Saline deposits associated with fluvial fans. Late OligoceneEarly Miocene, Loranca Basin, Central Spain J. ARRIBAS and M. DÍAZ-MOLINA

C9. Shallow carbonate lacustrine depositional controls during the Late Oligocene - Early Miocene in the Loranca Basin (Cuenca Province, central Spain) M.E. ARRIBAS, R. MAS and M. DÍAZ-MOLINA

S1. The Betic Neogene basins: introduction CH. MONTENAT

S2. Neogene palaeogeography of the Betic Cordillera: an attempt at reconstruction C.M. SANZ DE GALDEANO and J. RODRÍGUEZFERNÁNDEZ

S3. Depositional model of the Guadalquivir - Gulf of Cádiz Tertiary basin C. RIAZA and W. MARTÍNEZ DEL OLMO

S4. Late Neogene depositional sequences in the foreland basin of Guadalquivir (S W Spain)

F. J. SIERRO, J.A. GONZÁLEZ DELGADO, C. J. DABRIO, J.A. FLORES and J. CIVIS

268 S5. Miocene basins of the eastern Prebetic Zone: some tectonosedimentary aspects

CH. MONTENAT, P. OTT D'ESTEVOU and L. PIERSON D'AUTREY

S6. Stratigraphic architecture of the Neogene basins in the central sector of the Betic Cordillera (Spain): tectonic control and base-level changes J. FERNÁNDEZ, J. SORIA and C. VISERAS

S7. Pliocene-Pleistocene continental infilling of the Granada and Guadix basins (Betic Cordillera, Spain): the influence of allocyclic and autocyclic processes on the resultant stratigraphic organization

J. FERNÁNDEZ, C. VISERAS and J. SORIA

S8. Late Neogene basins evolving in the Eastern Betic transcurrent fault zone: an illustrated review CH. MONTENAT and P. OTT D'ESTEVOU

S9. Tectonic signals in the Messinian stratigraphy of the Sorbas basin (Almería, SE Spain) J.M. MARTÍN and J.C. BRAGA

S10. Basinwide interpretation of seismic data in the Alborán Sea C. DOCHERTY and E. BANDA 


\title{
W7 North-western Cainozoic record: present knowledge and the correlation problem
}

\author{
A. MARTIN-SERRANO, R. MEDIAVII.I.A AND J.I. SANTISTEBAN
}

\section{Abstract}

Tertiary deposits of the north-wcstcrn Itcrian I'eninsula are heterogeneous because they uccur in scveral morpho-structural positions as isolulcel and dispersed basins and outcrops. The quality of the palacontological record is usually very poor and there are scarce data. Correlation depends on a wide range of critsria which are not always equivalent: palaeontology, mineralogy and petrology. geomorphology, lectonics and comparison with better-known and better-dated facies in regions ncarby. The results lack homogeneity and there arc notable discrepancies.

\section{Intmduction}

Tertiary sediments of Galicia, Bierzo and the Cantiabrian Range (north-western Spain) occur in small basins and isoluled outcrops.

\section{Galicia Basins}

Many geographical features and the Tertiary basins of Galicia are relaied to fault-systcms trending N-S, NN L-SSW, NE SW, E-W and WNW NW-E.SE SE (Fig. 1).

\section{Lugo Basins}

The most important outcrops of Tertiary sediments in Galicis arc located in I.ugo, between the central peneplain and the castcrn mountains. The main basins (Terra Cha, Sarria and Monforte) are asymmetrical: Tertiary sediments rest unconformably upon Palaeozoic rocks in the west and arc separated from crystalline basement (igncous rocks) hy N20-30 and N50-60 faults (Fig. 2).

The scdimentaryfills of the Sarria and Monforte basins, up to 200 $\mathrm{m}$ thick, have been divided in various stratigraphical schemes (Birol \& Solé, 1954; Brell \& Doval. 1974. 1979; Virgili \& Brell. 1975; Martin-Serrano, 1979, 1980, 1982; dcl Olmo, 1986; Vergnolle. 1984. 1985, 1987. 1990) with several Jithostratigraphic units which were grouped into the Montcforte Formation (Vergnolle, 1988). The sedimentary record of the larger basins includes two superposed megascquences of opposed trend (Figs. 3, 4), but it is difficult to differentiate thesc tronds in the smaller, moderately subsiding basins. The luwsr. fining-upwards megasequence compriscs:

- Grcen arkoses with minor clay mralrix (smcctite) atranged in channel-form boujes separated by mud layers. These are intcipretcd as the deposits of rivers that flowed from the granite area of Villalba-Chantada.

- Red-green alluvial-fán conglomerales. Thuse are deposits of small, but thick. alluvial corres rovited in the melamorphic and granitic source areas of the castcrn cdges of the basins.

- Banded, red-green induratcd clay series in the areas wherc the arkoses and conglomerates coalesci. This facics is morc extensive upwards and there is also a progressive

the generation of dolomitic crusis associated with palygorskite and stpiolitc (Sarria Basin).

The upper, coarsening-upwards megasequence contains gieen arkosic gravel as the last dcposits of the basins infill.

\section{SE Galicia}

Three distinct basins occur in the small tilted (towards the Sand SE) mounlain blocks of Orensc: Maceda, Ginzo de Limia and Verin.

Miaccla is a complex, $160 \mathrm{~m}$ deep. half-graben bounded to the NNF: by a large fault scarp. The lithofacies arc differcnt from those of the Iugo basins: the largest part of the basin fill is a finingupwards fluvial unil of finc-graincd sediments (Del Corno and De la Vega Members of Brell. 1975: Dc los Milagros Member of del Olmo. 1986). They are white, grcy and ochre ferruginous sand and c. lay ( $55-65 \%$ kaolinite) with organic matier, deposited in Iuviatilc environments. The marginal sediments are red muddy sands and gravel. comparable with one of the lithofacics of the Monforte Formation; they are interpreted as alluvial-fan dcposits related to the lectonic activity of the border. 


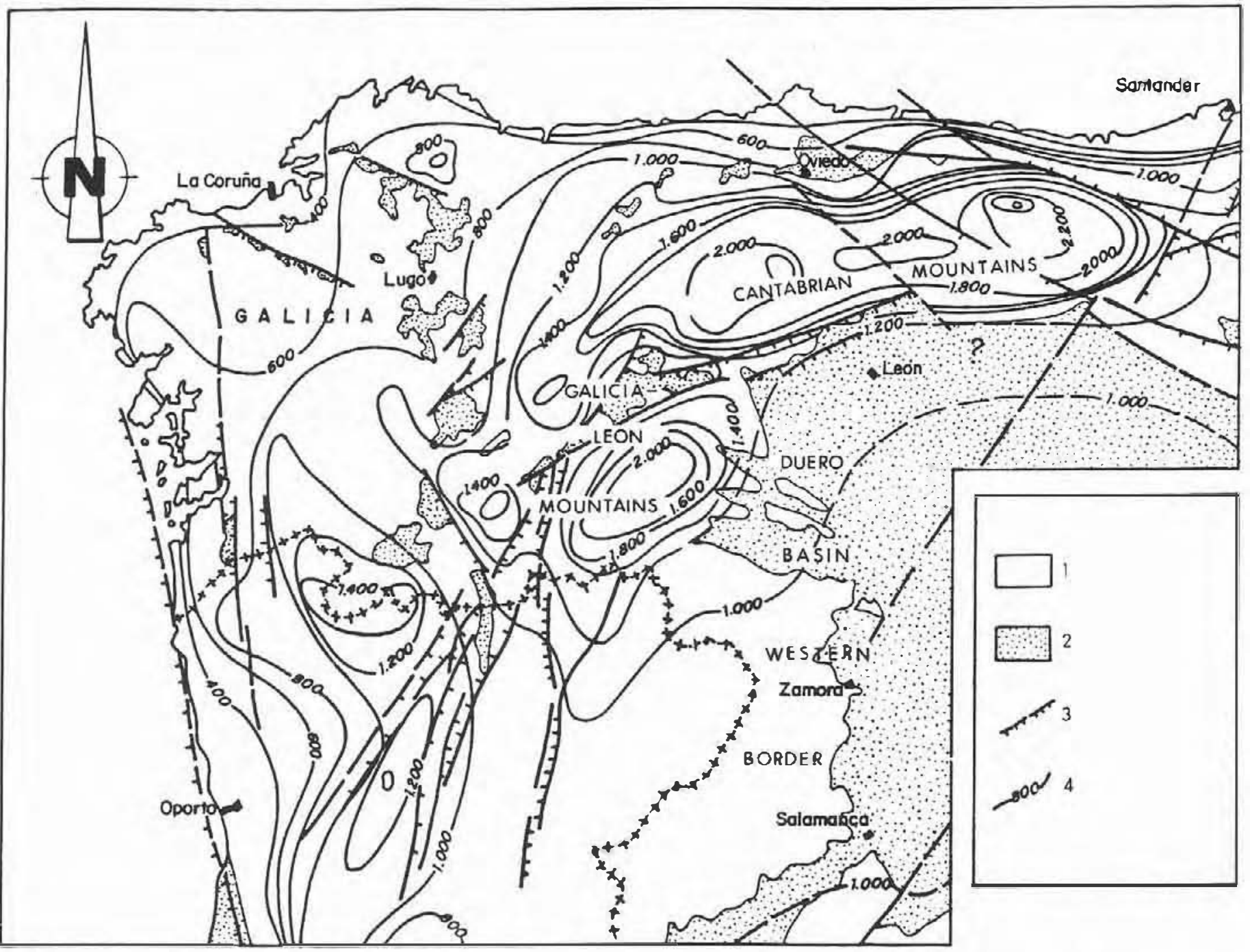

Fig. 1. Morphustructural situation of the north-western Tertiary. I: Palaeozoic basement and Mesozoic: 2: Cainozoic: 3: Morphotectonic lines: 4: Isohypses of relief contours.

The Ginzo de Limia Basin is a sub-Recent tectonic trough hounded by N70, N-S and NI20 laults and filled with alluvial sediments. The fill consists of 250 in of Tertiary sediments. includinga lignitc and clay layer, located betwecn 80-130 m in depth. and interbedded belween two lhick sandy series (ICiMFi, 1979-1984).

The narrow Verin Basin, in the morphostructural region of TrasOs-Montes. reaches a maximum depth of $100 \mathrm{ml}$ and is filled with red and grey clay. sand and gravel.

\section{Littoral Basins.}

These are small, isolated sutcrops Some of them are related to a structural corridor (the so-called Depresion Meridiana, Nonn, 1966): Porriño, Deva and Salvatierra. Other outcropss (Fazaouro Fomation) arc located on the Cantabrian side (Moucide. Burela and (.orenzana), and they are interpreted as a piedmont (Vergnolle. 1988) made up of finc siliciclastic scdiments related 10 a regressive episode. These are siderstithir lacics, with maturc constituents from a mineralogical and petrological point of view: kitoliniteand unalterable minerals. They arc comparable with Maceda. Ginzo de Lintia. Pucntcs de Garcia Rodriguez and Mcirama hasin fills. The Meirama Basin contains the best developed C'ainozoic record ol these fiacies,

The basins of San Satumino-Pectroso-Mocxhc-Pucntes-Ronlpar-Moī̄onovo and Lendo-Mcirama-Visantria-JuanceslaLatika-Orros-Boimil arc related to dextral faults (Fig. 5) that strongly infuenced the scdimentation (Maldonado. 1977: Garcia Aguilar, 1987; Mouge, 1987; Bacelar et ul. 1988. 1991 ; Santanach ef (1., 1988). They werc small. complex, compartmentalised, asymmetrical and strongly subsiding basins (Fig. 6) filled with green. grey and blue kaolinitic muds and sands. In some basins (Pedroso. Puentes de Garciat Rodrisues. Roupar, Juanceda and Meirama) there is lignitc as wcll. They were filled by small alluvial and fluvial systems associated with lacustrine and paludal environments (lig- 


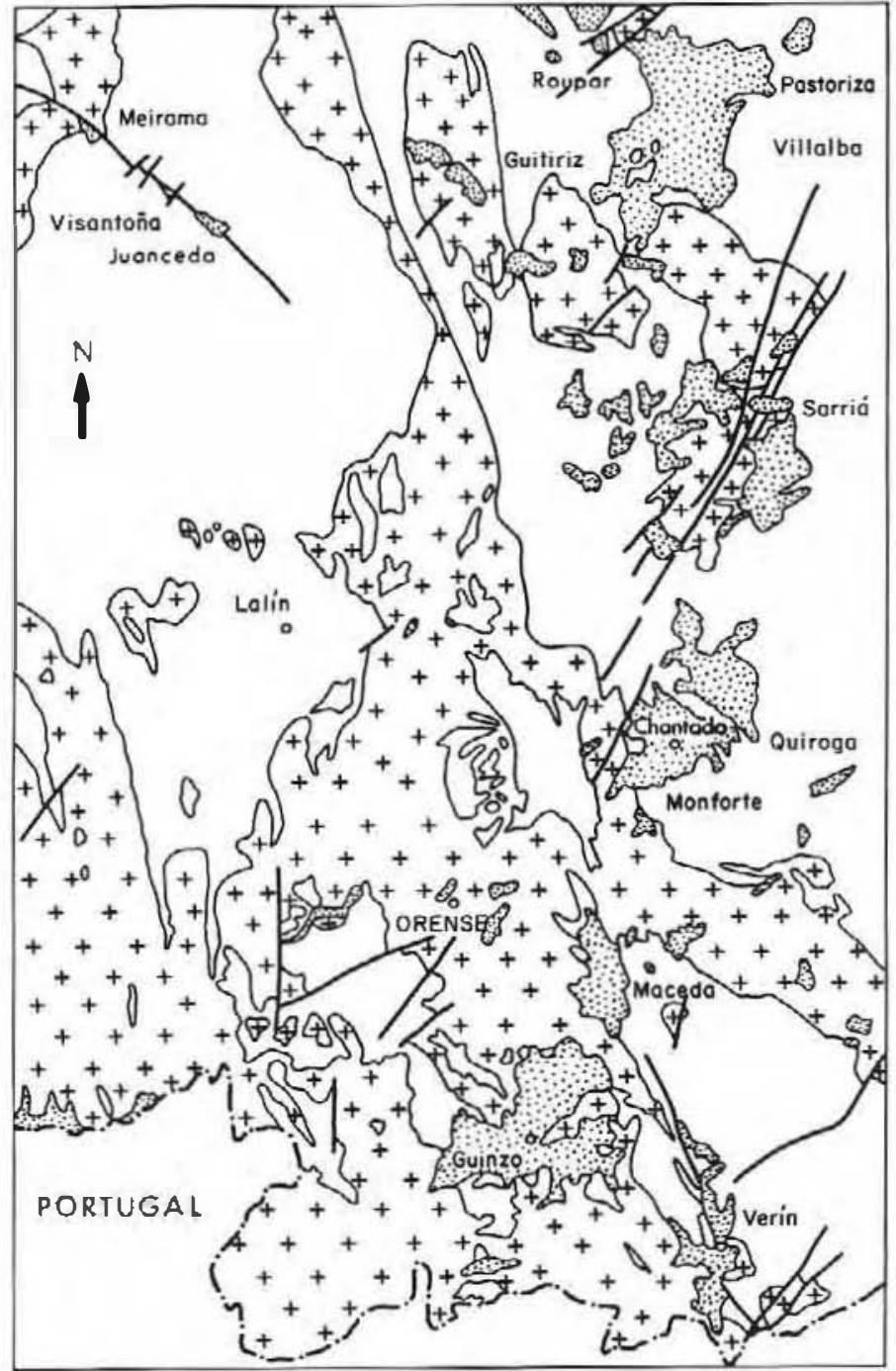

$++1 \quad \square 2 \quad \square{ }^{3}$

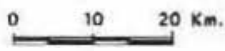

Fig. 2. Terriary hasins in eastern Calicia. 1. Igneous rocks; 2. I'alacoroic and pre-l'alaeozoic basement: 3. Cruinuruic.

nitc and curbonaceous clays) and were controlled hy thcir structura! evolution. Successive cxtcnsional or compressional phases in the basin of I'uentcs wcre recorded as expansions and retractions of the lignile beds. Equilihrium betwcen subsidencc and sedimentation favourcd the development of thick coal deposits in the Miramar Basin (Santanach el al., 1988).

\section{Sil corridor}

This is the depressed axia! area of a NE SW-lrending mountain systcm. The complex Bierzo Basin (Fig. 7). is the most important Tertiary development. It is a depression with two largt basins (Ponferrada Villafranca and Remhihre) surrounded by secondary subbasins to the notth (Parradaseca. Finolledo, Fabern
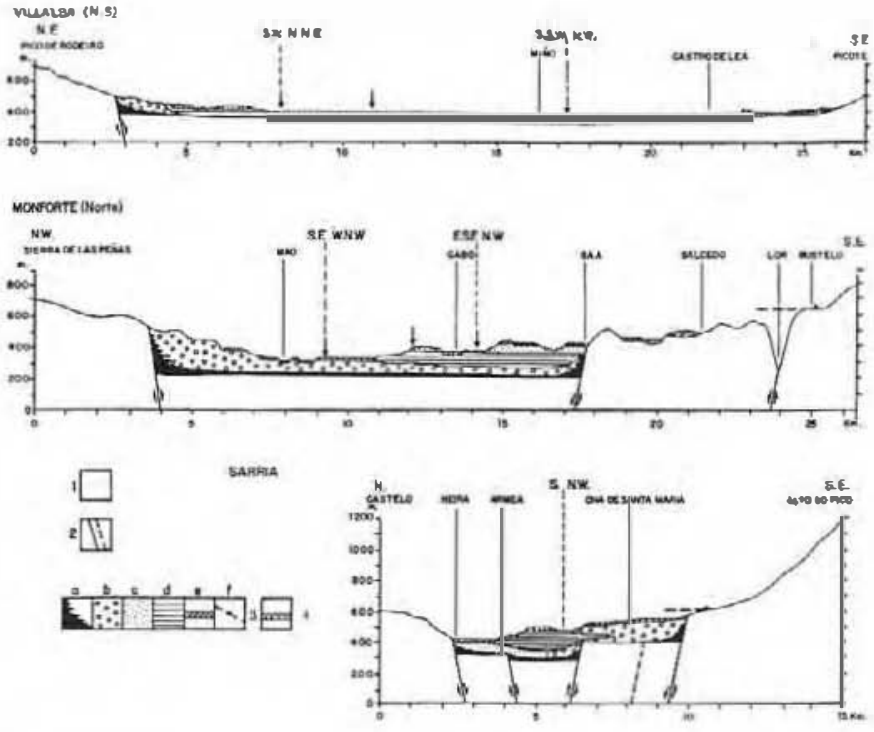

Fig. 3. Litliostratigraphy of the main hasins of Lugo Province (from Vergnolle. 1988). I. Basement; 2. faults; 3. Cainozoic deposits; a: brecclas; b: conglomerates; c: arkoses: d: clays: e: dotomltic crust: f: blocks of infill: 4: Quatcrnary alluvial sheet.

and Noccda) and south (Las Medulas and Carucedo). The other southern depressions (El Barco de Valdeorras, Lis Rua, Quiroga and Quintela) arc small, narrow. fault-bounded deep basins.

The up $10700 \mathrm{~m}$ thick sedimentary fill of thc Bicreu Basin can be divided into several units (1.ig. K) (Vidal Boix. 1941, 1954; Birot \& Solc. 1954: Pannekoek \& Sluiter, 1964; Delamire-13ray, 1977: Hcrail, 1979. 1981, 1984) which serve as a model for the remaining Sil basins:

- Toral Formation: fluviatile gravcl and sands and paludal limestonc antd dolostoncs (crusts). These are green to pink polymictic smectuic-rich sediments with feldspar, micas and polymıneral granns. Sourcearcasare far away to the west with a few local sources (fiig. 9).

- Santalla Fonmalion: beige-ochre or grey-red siliciclastic conglomeratcs and muddy sands deposited in continuously flowing, high-compclence fluvio-torrential alluvial fans.

Las Médulas Forınation: matrix-rich siliciclastic gravcl with boulders, deposited in high-competcncc. intcrmillcnlly !luwing. alluvial fans.

- Thesc deposits are topped by a weat thered raria-like sheet of gravel.

All Sil basins underwent a similar evolution as wilncsscd by the similarity of their sedimentary rccords. The Quiroga Forination forms the lowcr infill of the Sil basin. and is laterally equivalent to the Toral Fonnation: the overlying Monforte Formalton has fluvial faciescomparable with the Santalla Formation (Figs. 10 and 12).

Morphotectonic features are evident in the Bierzo Basin (NESW and E W borders) and all alongthe Sil Valley (with narrow and 

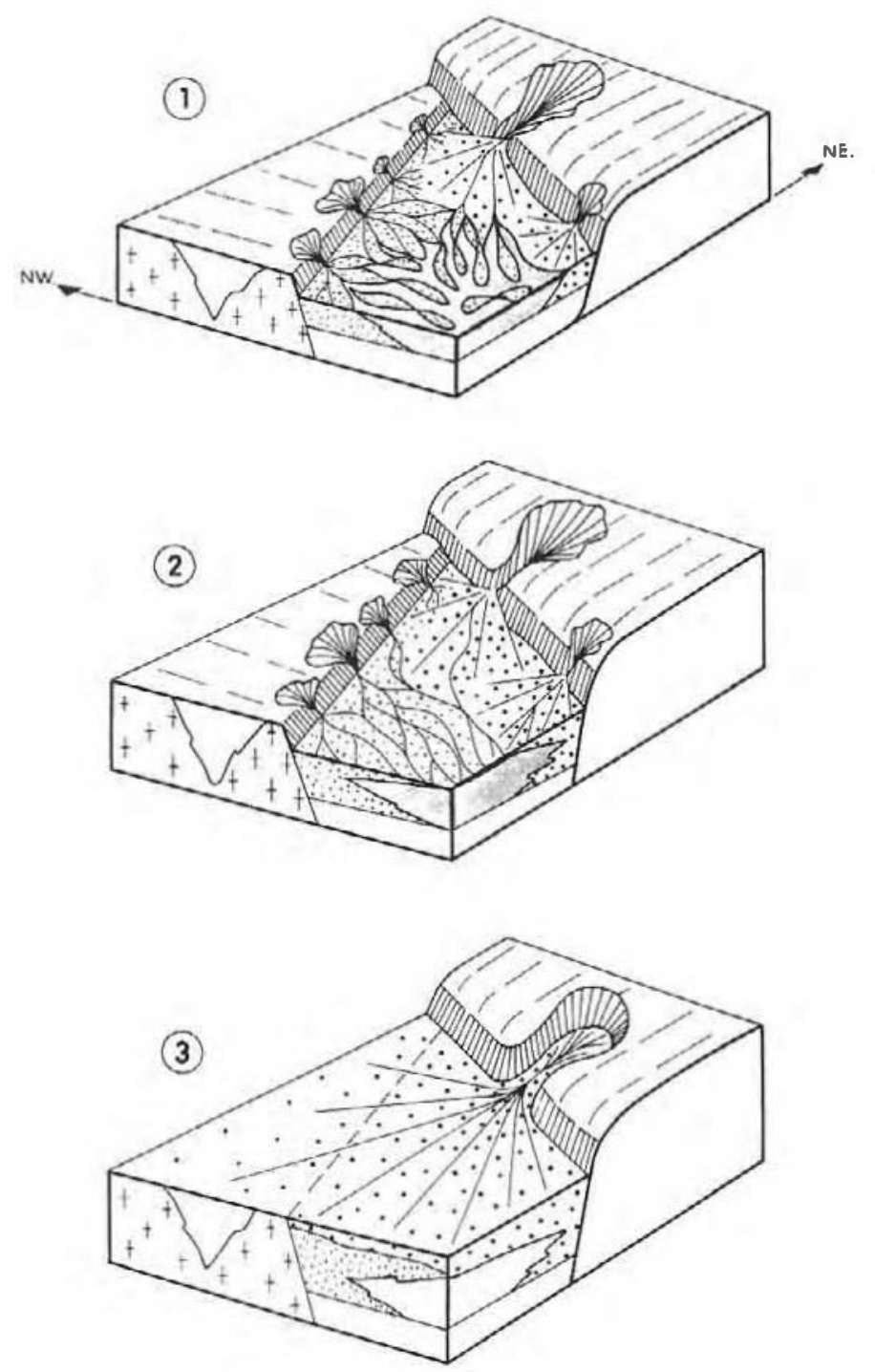

Fig. 4. Palengengraphical recorstruction of the basins filled by the Monforte Formation (simplified from Verginolke. 1988).

deep N50-60 and N140 basins) (Biro \& Sole, 1954; de Grool. 1974; del Olmo, 1986: Vergnolle. 1988). The infill of all thest: small basins shows a coarsening-upwards scqucnce. Strong deformation can also be seen affecting the Toral or Quirnga Formations. This deformation has not affcctcd younger sediments such as the Santalla or Las Médulas Formations. The former are syntectonic deposits synchronous with the opening of the Bicrzo Basin and J.ugo basins.

\section{Asturias outcrops}

The Cantabrian Range, an old massif uplifted and deformed from L .uletian to Nengene times, is divided into mountain massit"s,

Surco Prelitoral (pre-littoral furrow) is a tcctonic scar with fragments of Permian and Mesozoic rocks that contains almost all the regional Teriary record in discuntinuous outcrops (La Espma. Grado. Oviedo. Infiesto, ...) witlı a relative concordance of facies (Llopis Lladó \& Martinec Alvurce. 1958. 1959, 1960): ICiME, 197984, 1986: Truysls el al.. 1991).

The contincnlal Tertiary deposits, up to $250 \mathrm{~m}$ thick, between Oviedo and Inticsto rest upon the karstificd top of Upper Crctacenus carbonate rocks. They can be divided into two units (Truyols ef (al. . 1991): a lower mud ustit with ycllow-red or grey-green sands is overlain by red-yellow clays and marls with calcareous sands and brecciated limestone rich in gasıropods and ostracois of Oligocene agc. To the north. these two units change laterally into calcareous gravels and breccias (Pudinga de P(isuda).

Three units have been difierentiated in Grado:

$\wedge$ lower fining-upwards scyucnce of conglomerates and sandstone with carbonate cement and laminated, husrowed muds of braided river origin.

- A thick intermediate coarsening-upwards unit of clay and laminated mud passiriz upwards into conglomerates and sandstone with intcrealations of laminated. burrowed muds. This is intcrpreted as sediments of cphemeral river systems and flood-plain deposits including ljmestone and marls.

- The top of the section consists of alluvial-fan, massive gravel. supplicd from the south.

The westernmost fragments of this Tertiary Asturias liasin nccur isolated and perclicd high ncar Pola de Alande. They are alluvialfan dcposits that change unwards to lluvial facies; they are related is a structural line. The proximal fan facies are massive gravels with sands and hurrowed muxts; distal fan and fluvial facies cousist of gravels, sands and green burrowed muds (IGME. 1986).

All these oucrops act the remainsof a unique basin that exicnded from east to west with un active northern boundary I/ ramja Móvil Intermedia) which governed scdimentation and strongly inlluenced the terminal teciofacies (Pudinga de Poscula). Faults broke up the outline of the basin and parts of it werc croded some time afterwards.

\section{Straligraphic correlation, fragmentation, Cainnznic variety and dispersion}

As previously indicated. the Tertiary of the north-west is varied bccause it is located in several morphostructural positions. which are isolated from wich other. Furthermorc, outcrops are usually of very pour quality and the palaeontological record is scarce. As a conscquence, correlation depends on a wide range of critcria which are nol always cquivalent: palaeontology, mincsalogy and pctrology, geomorphology, tectonics and comparison with better known and dated facies in regions nearby. As cxpected. the results lack homogencity and contain notable discrepancies (Fig. 12).

Pulaeontological data arc scarce, frequently confirsedrawdariol dcep fluvial disagrcemen 1 with other data; in tact these data play a negative role because they impose forced correlation. The reason is that the 

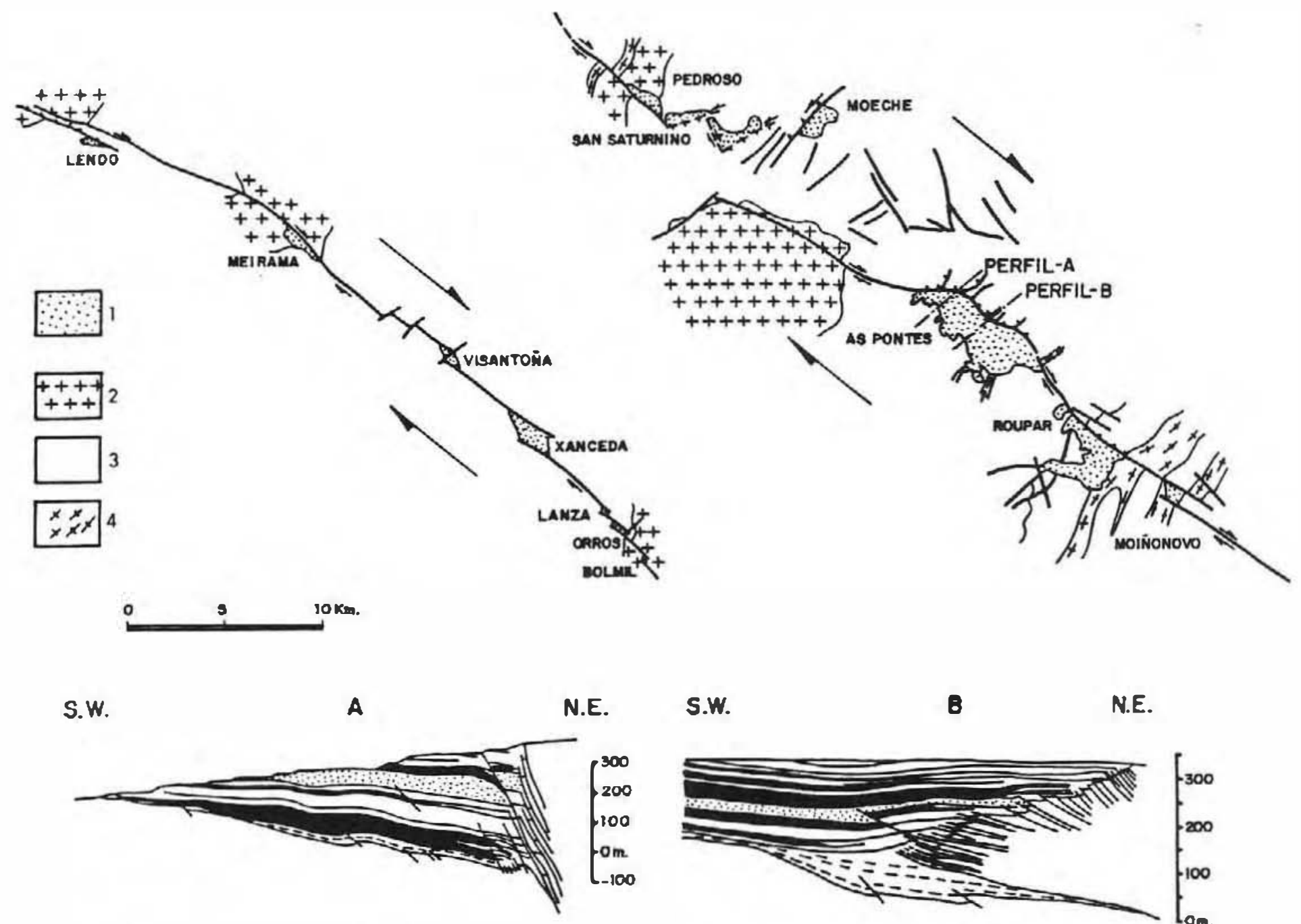

S.W.

B

N.E.
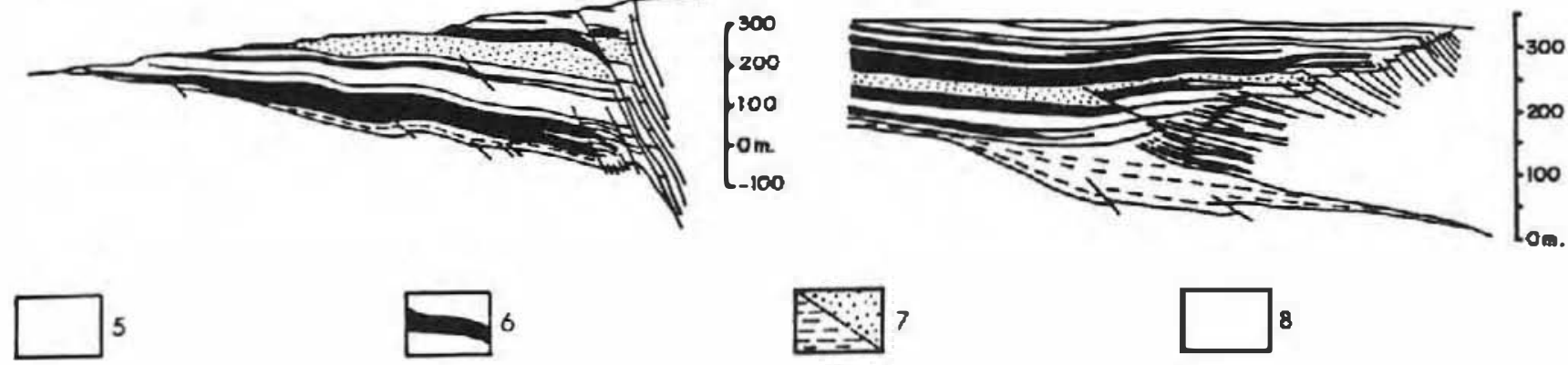

Fig. 5. Tectonic basins of Meirama and Puentes de Garcia Rodriguez with l wo tratusucrue trons-stections (Pertil-A

of sediments in l'uentes de Garcia Rodriguez basin (from Bacejar et al., 1988 and Suntunuch et al., 1988). 1: Cainozoic; Palaeozoic, 2: Igneous rocks: 3: Quartzites and slates; 4: Schists and other metasediments: 5: Palaeozoic basernent; 6: Cołl dumiusted iulerbcdding (siliciclastic beds subordinated): 7: Silicictuslic alternances (nithout coal beds); 8: Coałailiciclastics alternation.

palaeontoingical assemblages are poor: only some layers of vertebrates and charophytes ncar Oviedo, dated as Rhenanian Headonian in age (Truyols et al.. 1291), and palynomorphs in lignitc beds in the Coruva hasins, attrihuted to the Middle-Upper Miocene 10 Pleistocene (Medus, 1963; Nonn \& Medus, 1963; Menéndez Amor, 1975: Maldenado. 1977: Araujo el al. 1988). Recently. (thesc sitcs also yielded verichrates of Oligocene-1 ower Miocene age (Fisteban el al. 1989).

The problem is that Cainozoic outcrops show a greal variability of thickness, facies, seyuential arsangentent and petrologsc and mineralogical composition. Such a diversity seems incompatible with the idea of a unique (and coeval) palaeogeography and palaenclimate as especially suggested by the basins in Galicia. In some areas, there are siderolithic facies and lignitc (Allantic basins), whereas in others, arkosic scdiments dominate (Lugo basins). Is thcre a single genlogical background for all these basins? An alfirmative answer implies that the age ranges belween $U \mathrm{PJ}_{\mathrm{T}} \mathrm{C}_{\mathrm{T}}$ Oligocene and Neogenc and also requires an explanation for the divcrsity of facies in ierms of local palaengeographical and palaeo. geomorphological features (Birot\& Solé. 1954; Nonn. 1966; Brcll\& Doval, 1974). If the answer is negative, the diversily has to be explained as the result ol stratigraphic superposition (Fig. 13), which impliesdiscontinuous sedinentation in steps and a prolongation of the time-duration of the stratigraphic record (Martin- 


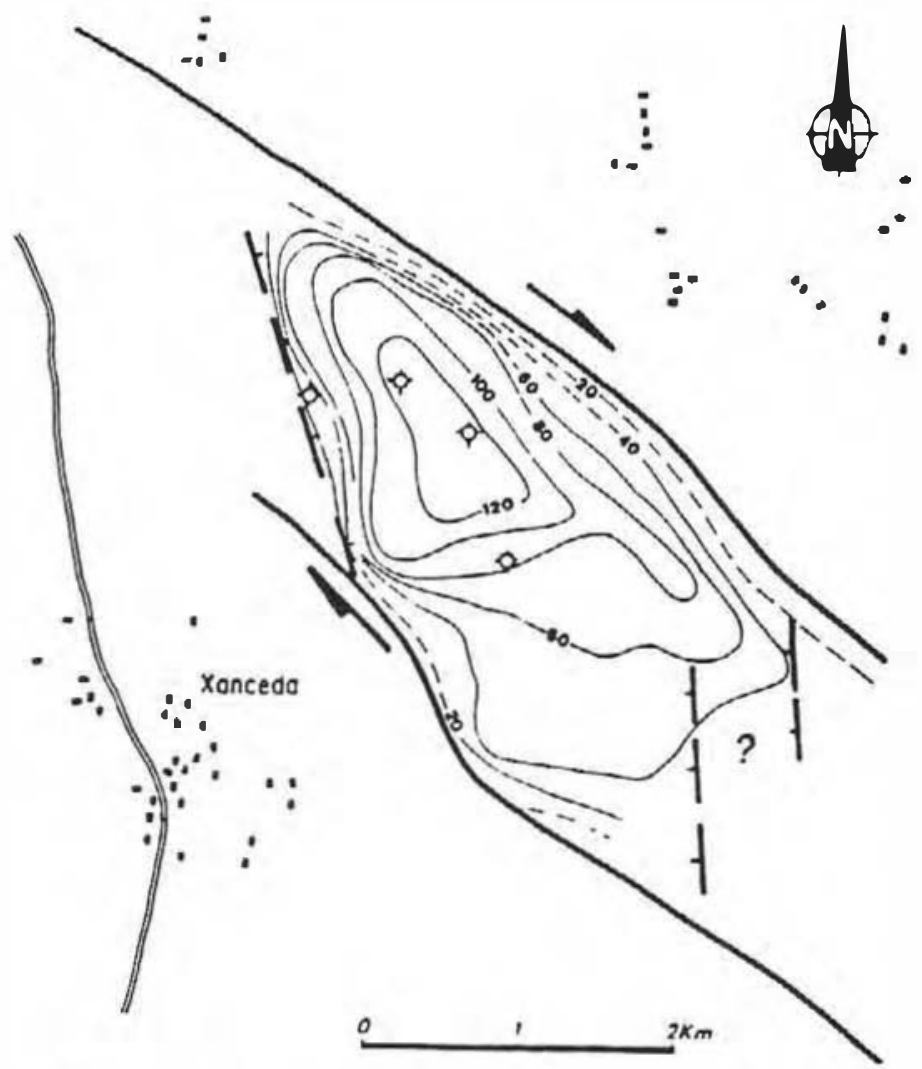

Fig. 6. Structural scheme of Xanceda Basin. Basement isobaths deduced from electric and mechanical vertical drillings (from Santanach et al., 1988).

Serrano. 1982; Vergnolle, 1988). In this second modc. it is possible to correlate the basins of Galicia with the Duero Basin via the Bierzo Basins.

As with other major geofogical beits. the north-western Cainocoic basins werte controlled by several fault systems leading to the analysis of the different basins on the basis ol parlicular lieatures. These leatures can be correlated to olher lithostratigraphic or geomorphologic attributes. but these comparisons lead straight back to the basic probicm: poor knuwledgc of the age and succession of gentecinnic and geomorphologic events due to the poor chronostratigraphy of the associated sediments. On the other hand. crosion surfaces have been largety obliterated by faulting. For this reason, a confusing variely of gentectonic bypothescs have becn proposed; for example: that the Pyrenean. Saavicor former Alpinc phases were responsible for initial tilting and tbat morc recent topographic changes and instability (evident through the Neogene) extends uniil Plio-Quaternary ıimes.

This problem can only be overcome by the combination of geomorphologic. Iccionic and stratigraphic studiss. Systcmatic analysis should focus on geomnrphologic investigation hecause. in these Tertiary studies, rclief is not only the palaeogeomorphological context of the basins but also the rusult of the Alpine gevtectonic framework. This apnenach makes it clear how important the study of weathering profiles, as "alterites' is likely to be. These occur both still resting upon the basement and also incorporated into the Tertiary sediments, hecausc through time the main bulk of alterites must have been eroded and incorporated into the basin tills. Then it should be possible to compare sedimenis and weathering profiles and in consequence corrclate them with planation surfaces. With a special link like the altcrites, wc can plan to correlate the lithostratl. graphy of basins with the evolution of relicf and vice-versa.

\section{References}

Araujo, P. Hernández-Enrile, J.L. and Seara. J.R. (1988). Tectónlica cxicnsional y cstructura de la Cuencit de Maceda (Cialicta Mcridional). // Congr. Cieol. Esponia. 2: 107-110.

Bacelar. J., Alonso. M.. Kaiser, C.. Srincliez. M., Cubreru, L., Sírz. A. ante Sanlanach, P. (1988). Lit cuenca lerciariad de $\Lambda_{s}$ Ponles (Galica): su desarrollo asociado a inflexiones contuactivas de una falla direccional // Congr. Gcel. Essuño, Simp.: 11 3-1?1.

Bacelar, J., Alonso, M., Kaiser, C., Sánelıez, M., Cahrera, L., Fcrras, B., Sáe7, A. and Sanlanach, P. (199!). Relaciones tectónica-sedimenfación de la cueoca cennzoica de As l'ontes (A Coruña). I Congr. Grupo Español de Terciario, Comun.: 25-27.

Birot. P. and Sole Sabaris, L. (1954). Recherches morphologiqucs dans lc Nord-Oucsi de la l'éminsule Ibériquc. Mem. el Voc. Cemire Doc. carr. er Ciéograph. C.N.K.S.. 4: |1-61.

Brelf. J. and Duval, M. (1974). Un ejenplu de cur relaciül lıtestratigrifica aplicado a las cuencas lerciarjas del NO de la Penistsula. Estuel. Geol., 30; 631638

Brell. J. and Doval, M. (1979). Relaciones entre los sedimentos neógenos de Galicia y las aliericciones de su sutsstrato. Interprelación palcoclimálicas. Acta Grobl. Hispánica, 14: 190-194.

Delmaifc-Bray, M.M. (1977). Les grandes ćlapes de l'individualisation du hassin du Bierzo (Leon. Espagne) àpartir du Neogène. Mćditcrranée. 19-34.

Esteban. J.. Lopez. N. and De Lă Peña. A. \{(989). P'rospección dc micromamíferos fósilcs en la zona cle Galicia. Infurme Provecto Mapa Neotectónico. ITGE.

Gurcia Aguilar. J.M. \{1987). Caracterización estratigrafucit y tes:tonosedimensaria de la cuenca lignilifera de Meirana ( $\Lambda$ Corutia). Cuend Lab. Xeol. Laxe. $11: 37$ 49.

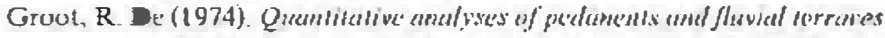
upplicel 10 the basin of Monforre de lemos, Goliciu. NW' Sprin Amsterdam, 127 [1p

Hesail, G. (1979). La sedimeniación Ierciaria en la parte occidental del Bierzo (Leño, España) y sus implicaciones genmorfológicas. I Reunión sobre la Geologia de la Ciunca diel Duero. Sulananca 1979. Temas Geol. Minl. 6: 323-337.

Herail, G. ([981). El Bicreo: gćomorphngénesc fini-lertiatrc d un batssin intra-montugncux (Espagnc). R.C.P.S.O.. 52 (2): 217-232.

Hcrail. G. (1984). Gicomorphologic et litologic de l'ur deltriticuc. Pieraonts el bassins iniranguntagneax da Nori-Ouest de l'Espagne. C.N.R.S.: 1456.

IGME (1979 \$4). Proyecto para la invesigación de lignito en la región th Galacia. Fases 1.111. Unpublished.

IGMF.(1986). Fxpłoraciōn lignitifera en la i egionn Astur-Galaica y experiencia piloto en la cuenca del Duern (Borde zamozano-lennés). Internal neport. $226 \mathrm{pp}$.

Llopis Lladó. N. and Martinez Alvarez, J.A. (]y58). Conlribucion al conocimiento del Terciario de los alrededores de Uviedo. Monograf. Geol.. 9: 287-304.

Llopis Llado, N. and Martincr. Alvarez, J.A. (1959). Esseudio hidrogeolúgico del Terelano de los alrederdorss de Grado. Estud. Geol. 24 287-304.

Llopis Ljadú. N. and Martiate. Alvare.. J.A. (1960). Subre el Terciariu 

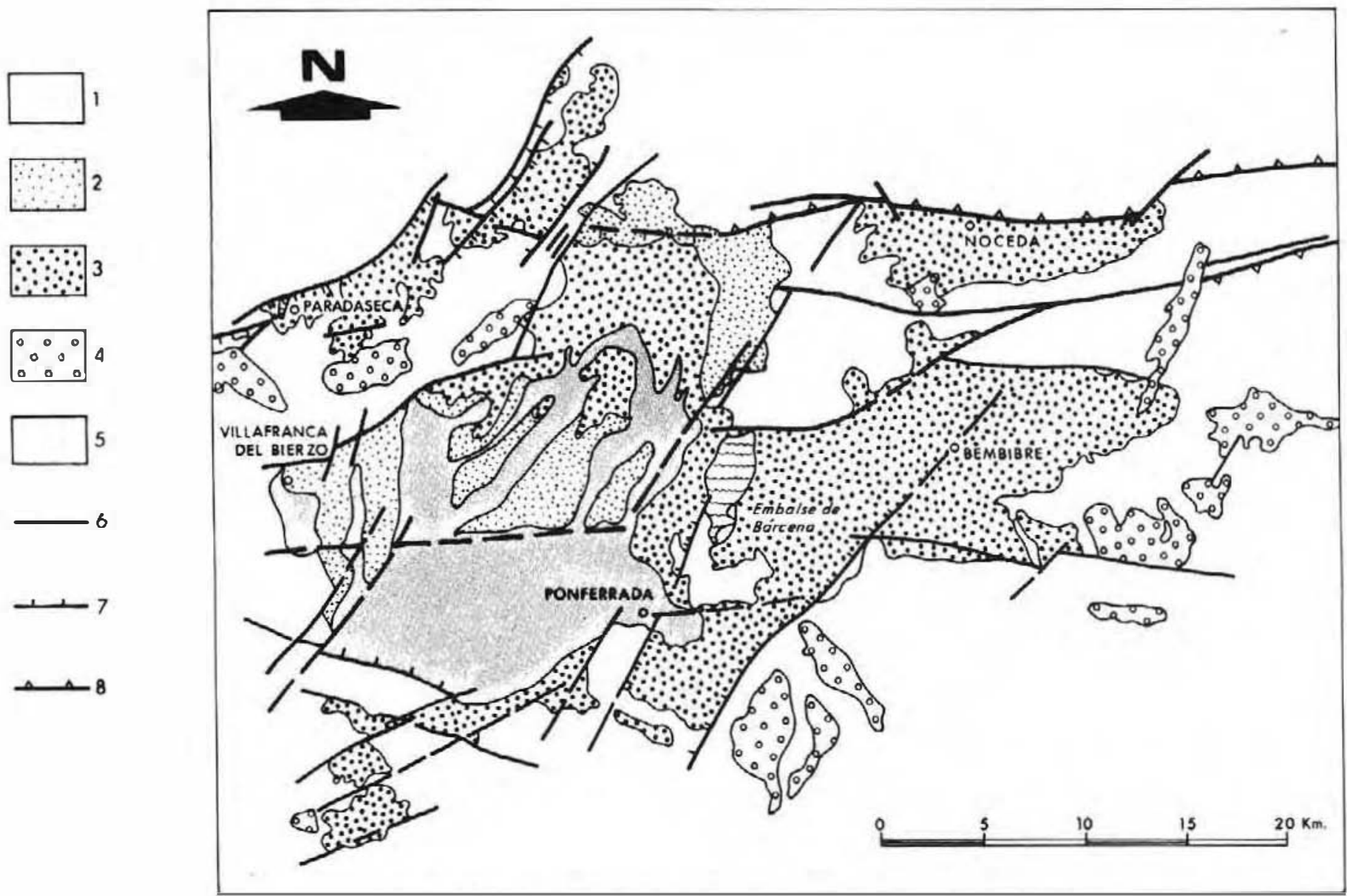

Fig. 7. Structure and sedimentating of Biern Basin (from Herail, 1984snd ICME, 1972 1984 and 1986). 1. Basement; 2. Toral Formation: 3. Santalla und 1,3ls Médulars Furmation; 4. uppermost gravels; 5. terraces (Quaternary?); 6. faults; 7. normal faults; 8. reverse faults.

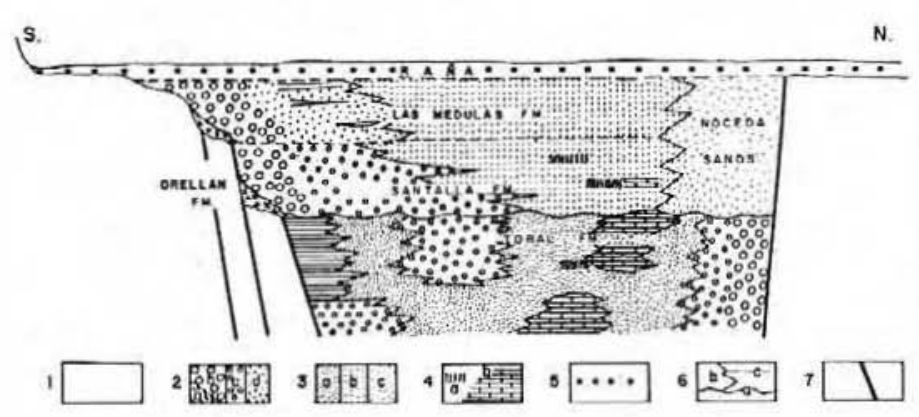

Fig. 8. Lithostratigraphy of the Bierzo Basin filt (fram Herail, 1984). 1. Basciucut: 2. gravicls: a. monogenic breccias; h. quarwite and sand stone blocks; c. rounded gravels; $d$. ntatrix-rich poor rounded gravels: 3. sandy, silty and muddy facies; a. smectile-rich, leldspar and quarteose sands; b. illite-rich, schist and quarteose sand:3; c. ilite-rich, quartzose sunds; 4 . carbonates (limestones and dolostones): a. isolated concretints; h. massive and tabulss Icvels; 5. raña, highly altered quartzite pebbles and blocks; 6. sedimentany discontinujty: $n$. discortiunco: b. lateral change of facies; $c$. vertical facies transition; 7. faulss.

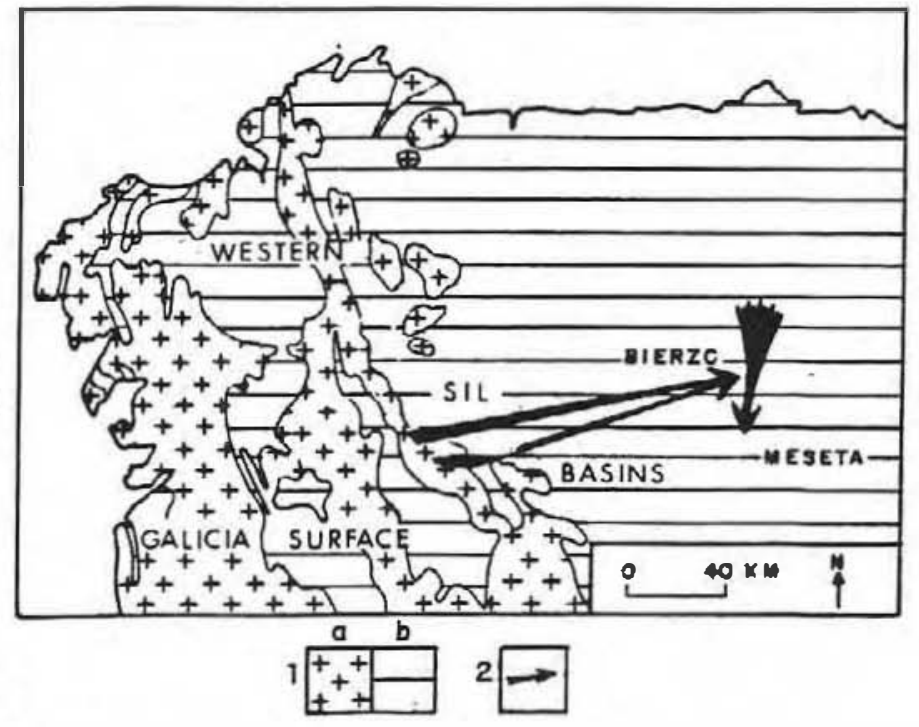

Fig. 9. Pylacecurrent directions measured in Lower Mlincene deposits nf northwestern Iberian Pcninsula (Vergnolle, 1988). 1. Basement: a. granitnids; b. metamorphic rocks; 2 . palaeocurreuts. 


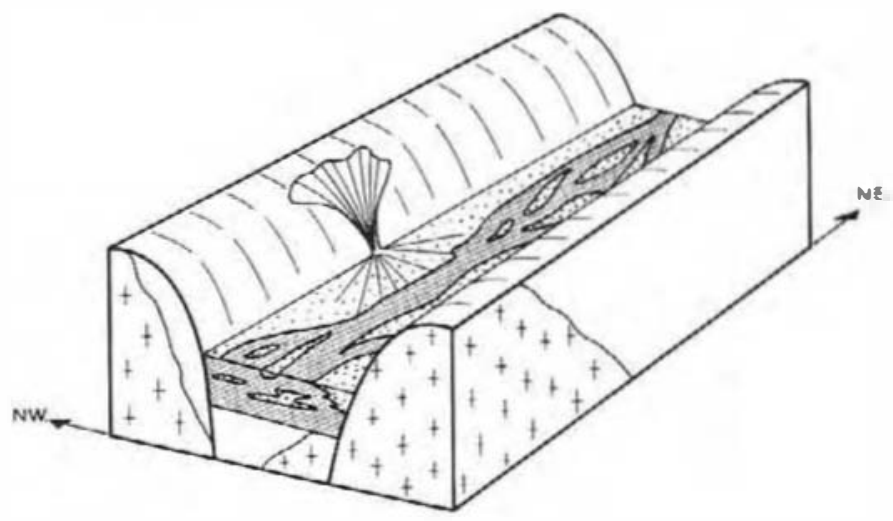

Fig. 10. Palaengeograplical scheme for Quiroga Formation (from Vergnolle, 1988).

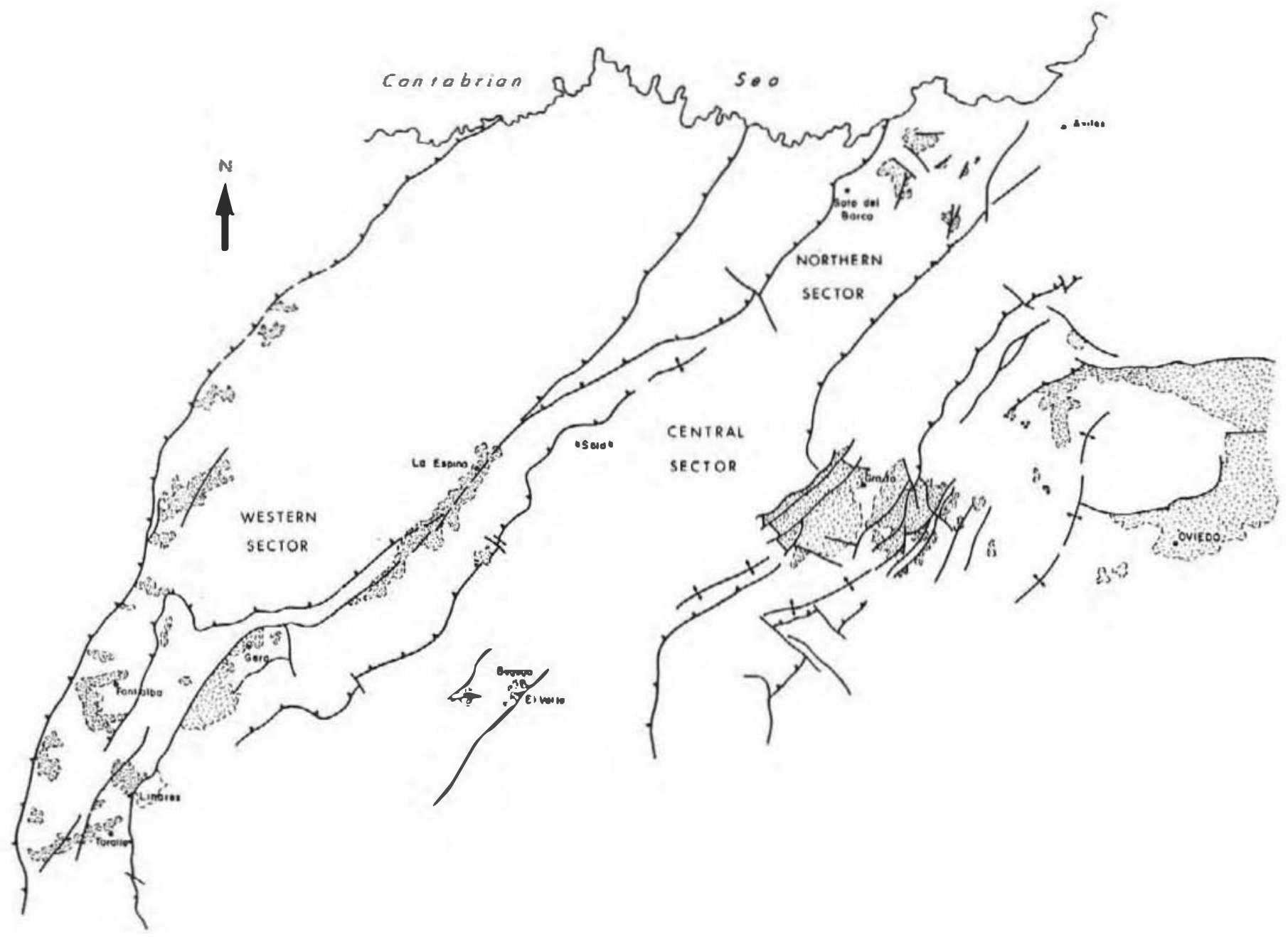

Fig. I1. Tertiary outcrops in western Asturias (IGi.lE. 1979-1984). 

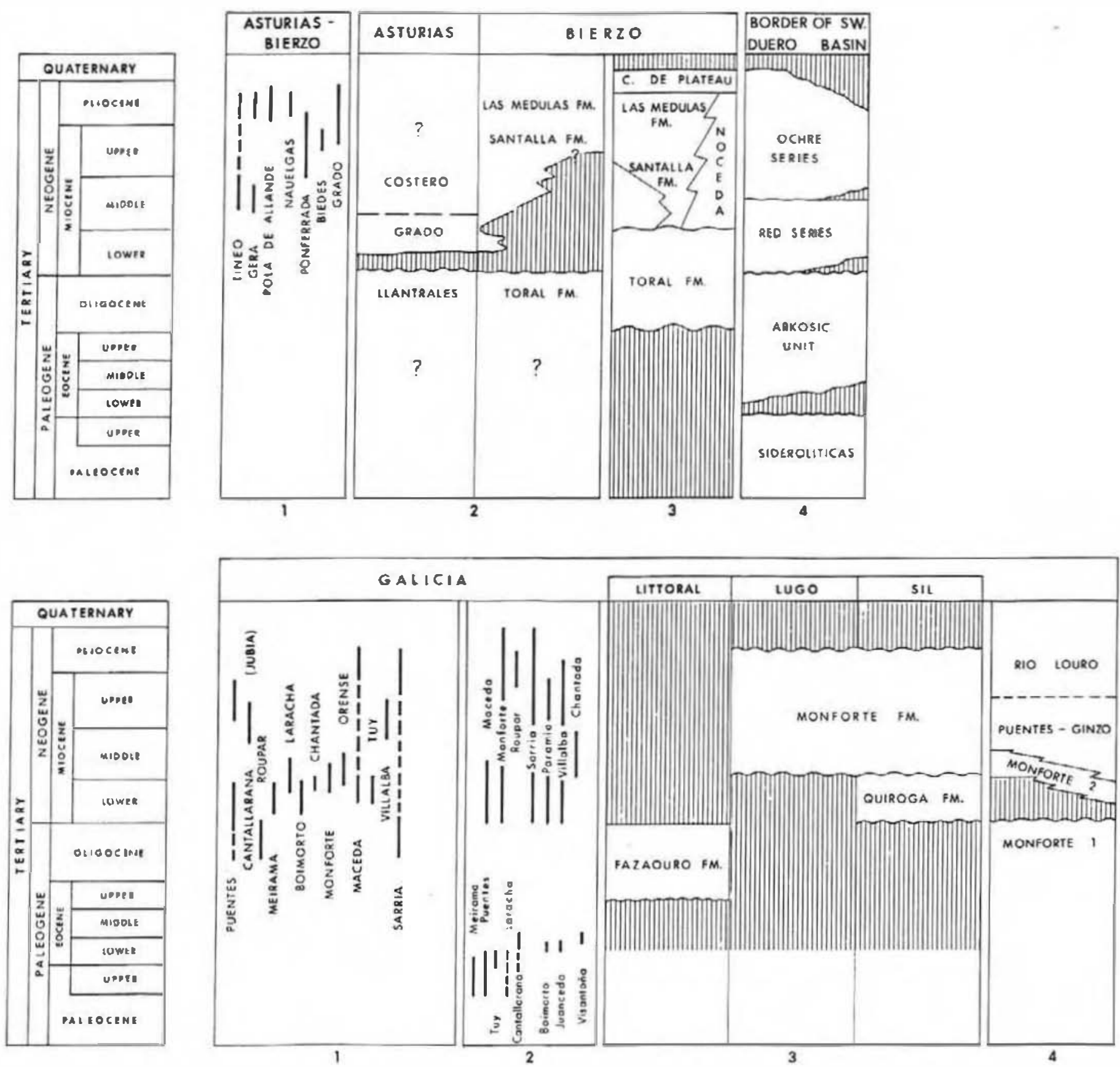

Fig. 12. Chronustratigraphy of Tertiarydeposits in notth-western Iberian Peninsula. L'pper rable: I. Brell \& Doval (1974); 2. 1CME(1986); 3. Herail (1984); 4. Santistehant'l al. (1991). Luncr Tablc: I. Brell \& Doval (1974); 2. Martin-Serrano (1982); 3. Vergnulle (1988); 4. IG:M1E (1986). 

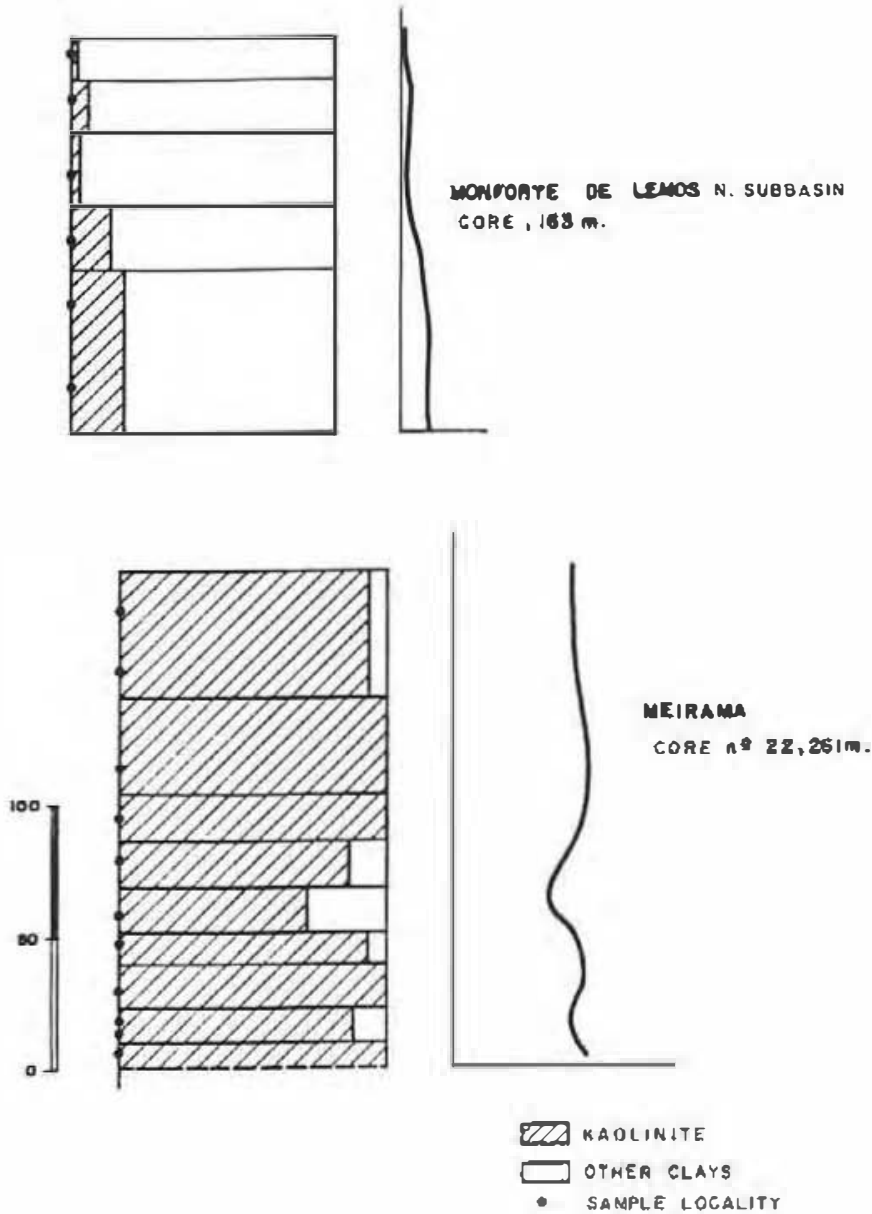

Fig. 13. Kaolinite propurtiun in clayss of tono difterent Galicia basiss (data for Meirama Basiu from Maidousdo. 1977: und dutu for Mlouforte de Leunosf rem Promotora ite Resursos Naturales, 1978).

cuntinental del cucidente de Ast urias y su significación mort otectönica. Brev. Geol. Ast.. I.II: 318.

Maldonado, A. (!977). Estudio geuligin:u geofisico del surco BaldavoMeisama-Boimil, Doctorall Thesis. Univ. Pulicis:n. Madnd. I:TSIM. Madrid.

Marlin-Scrrano. A. (1979). FI conoximienin del lignito y del Terciario en Galicia. Exposición y critica. Terniterrap. 31: 46-5.5.

Martin-Scrrano. A. (1982). El Tenciario de Galicia. Significado y posición cronoestratigsálica de sus yacimientos de lignito. Terniterrae, $\mathbf{4 8 :}$ $1-23$.

Martin-Serrano, A. (I990). Nouvelles hy'pothèses concernant la signilica- tion géologique du lignitc de Cialice (Now-One.sl te l'F.spagne) Ind. Min. Jes Techn. Juin: 249-258.

Menendez Amor. J. (1475). Hojer Geoksgica E. 1:50000 MAGNA no. 22 (P'uentedeume). IGME.

Mecius, J. (1963). Cortribution Palynologiquc a la connatsance dela flore el Se la vegetation neogene de l'ouest de l'Espagnc; ćtude des sediments recents de Galict. Thesse 3eme. syclc. Umv. Monipeslier. $91 \mathrm{pp}$.

Monge, C. (1987) Fstudio sedimentológico de la cuenca terciaria de Meirama. Lin ejemplo de cuenca sobre una falla de salto en dirccción. Cuad. Lab. Xeal. Taxe, 11: 51-67

Nonn, 11. (1966). Les regions coliéres de la Gialice (Espagne) Publ. Fac.des Lettres Univ. Strashourg. 3: 1-591.

Nonn. H. and Modus. J. (1963). Primeros resultados genmorfológicos y pałinológicos rct erentes a la cucnca de Puentes de Garcia Rndriguez (Galicia). Not. Com. Inist. Crol. Mineral. Esp.. 71: 87.94.

Olmu Sanz A. Del (1986). Estudio sedimentario de las cuencas Icrciarlas y cuatenarias de Munforle de Limos. Maceda y Qusroga. Ciuzd. Lab. X(col. Laxe, 10

Santanach, P. Balluille, J M.. Cabrera. L.. Monuge, C. Sác\%. A. and Victa] Romani, J.R. (1988). Cuenciss terciarias gallegas relacionadiss con corredores de fallis direccionilles // Comgr. Giol. Esspariu. simp.: 123-133.

Sluitcr. W.J. and Pannekock. A.J. (1964), "T: Bierzo'. Г:tude sérlimentologiquc ct gćomorphologique d'un bassin intra-montagtneux dans Ic Nord-Oacst de l'Espagne. Leidlsc Gerl. Meded., 30: 141-181.

Truyols, J., Garcia-Ramos. J.C., Casanovas-Cladellas, M.J. and Santatë Llopis. J.V. (1991). El Terciario de los alrededores de Uviedo. 1 Cungr. Grupo Espenolde" Terciurio. comun.: 334-336.

Vergnnlle, C. (1984) Lithostratignaplie Jes bissins tertiaircs du Nord-Esi de la Gralice (Espagne). Meilanges de la Cusa de V'ellizque:. 20; $372-392$.

Vergnolle. C. (1985). Géométric du remplissage des tass.sins de Sarria el de Monfortc (Galicc. Espagnc) el évstution géomorphologique rćgionalc. Mélanges de la Casa de Velazquez, 21: 3.31-346,

Vergnollc, C. (1987). Tertiary geomorphological evolution of the marginal bulge of the norih-west of the Iberlan l'eninsula, and lithostrat:graphy of the grabens of the north-east of Cialicia (Spain). In Gardiner. V. (ed.). Incrnutional gcomor pholog.y. 1956. Part II: 10631072 . Juhn Wiley \& Suns.

Vergnolle, C. (1988). Morphogenese des reliefs colicss assucxs a la marge continentale nord-espangnole. L'Excmpit du nord-est de la Gajice. Thèse de Doclorat 'noveau régine'. Univ. Toulouse Le Mirail: ?17 np.

Vidal Boix. C. (1941). Contrihucion al conocimienın morfológicn de li:s cucncas de los rios Sil y Miño. Bol. R. Sor. Esp. Ilist. Nut., 39: $(3-4): 121-161$.

Vidal Boix. C. (1954). Cicologia de los Montes Aquilianos y borde meridicnal de la depresión dei Biszo (Lcón). Homenaje a E. Hernández Pache'c\%, Bed. K. Suk. Esp. Hish. Natl.. speci, publ.; 677-67)5.

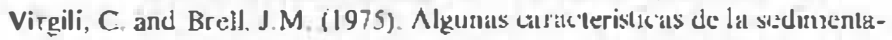
ción durante el Terciario en Gulicia. I C'mn. R. Sox. Esp. Hist. Nall., vol. extr.: 515-523 